\title{
Evaluation of Occupational Accidents in a Tertiary Emergency Department Introduction
}

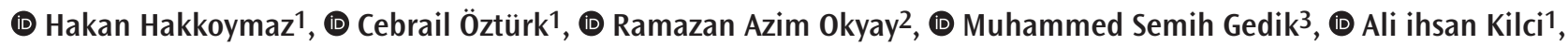 \\ (1) Özlem Güler ${ }^{1}$, (1) Fatih Nazmi Yamann ${ }^{4}$, (1) Mehmet Koșargelir ${ }^{5}$
}

${ }^{1}$ Kahramanmaraş Sütçü İmam University, Department of Emergency, Kahramanmaraş, Turkey

2Kahramanmaraș Sütçü İmam University, Department of Public Health, Kahramanmaraș, Turkey

${ }^{3}$ Kahramanmaraș Necip Fazıl City Hospital, Clinic of Emergency, Kahramanmaraș, Turkey

${ }^{4}$ Medipol University, Çamlıca Hospital, Department of Emergency, İstanbul, Turkey

5University of Health Sciences Turkey, Haydarpaşa Numune Training and Research Hospital, Clinic of Emergency, İstanbul, Turkey

\begin{abstract}
Aim: Our study aimed to determine the characteristics of occupational accident cases admitted to an emergency department and evaluate these accidents in terms of emergency service cost.

Materials and Methods: This descriptive study evaluated the age and gender of the patients, admission time, reason for admission and the sector in which the patient works. Trauma to the body area and the patients' cost covered by Social Security Institution were also evaluated according to the hazard classification for business organisations.

Results: The study included a total of 410 patients admitted to the emergency department due to occupational accidents. Of these, $95.9 \%$ were male, of which 30.0\% were working in construction sectors. The maximum number of admissions was between 800 and 1200 hours at a frequency of $34.6 \%$. Furthermore, the costs of occupational accidents that the workers were exposed to in very dangerous sectors were the highest $(p=0.012)$.

Conclusion: Occupational accidents result in the highest number of deaths after traffic and home accidents. They have a significantly negative impact on both the workers' health and national economy. In particular, in work places classified as dangerous and very dangerous, the employees are at a risk of accidents that may cause permanent injury and/or death.

Keywords: Occupational accidents, emergency department, costs
\end{abstract}

\section{Introduction}

An accident is defined as an event that causes undesirable and negative results that are unexpected, unintentional and incidentally occurring without a specific cause (1). The World Health Organization defined occupational accidents as follows: "Accidents are unplanned events that often lead to personal injury, damage to machines or tools and which may also stop production for a while" (2).

When the causes of occupational accidents were investigated, it was found in various studies that occupational accidents were 80-98\% related to human factors (insufficient personal protective equipment and unsafe behavior) and 2-20\% were related to nonhuman factors (physical, mechanical and technical disability). Considering all these investigations, the majority of occupational accidents can be considered as preventable accidents (3-5).

According to data from the International Labor Organization (ILO), 374 million employees are suffering from non-fatal workrelated injuries and diseases each year and it is known that more than 2.78 million people die due to occupational accidents and work-related diseases (6). According to the data of the Social Security Institution (SSI) in Turkey, 359,653 occupational accidents occurred in 2017. 83.6\% of the occupational accidents 
are male employees and $16.4 \%$ are female employees. In the year 2017, 1843 occupational accidents occurred in the province Kahramanmaraş, where our study was conducted. One thousand and seven hundred and six (92.5\%) of these accidents were male employees and 137 (7.5\%) were female employees $(7,8)$.

The most important outcome of occupational accidents is the death, injury or disability of employees. In addition, direct costs (hospital costs, compensations, SSI payments, penalties, etc.) and indirect costs also occur after the accident (workday loss, court costs, damage to and/or loss of equipment, work interruption, inspection process, mood disorders, loss of prestige etc) (4).

According to the data of ILO, it is reported that the total cost of occupational accidents and occupational diseases in the countries which have completed industrialization varies between $1 \%$ and $3 \%$ of the Gross National Product (GNP) of these countries. For developing countries, this cost is estimated to be $4 \%$ of GNP (9).

Many cases apply to hospital emergency departments for different reasons and occupational accidents constitute a significant part of them. In the case of injuries caused by occupational accidents, the first intervention is usually carried out in emergency services. These emergency procedures also bring forensic and ethical responsibilities to the emergency department physician $(10,11)$. The aim of our study was to define the demographic characteristics of occupational accident cases applying to an emergency department and to evaluate these accidents in terms of emergency service costs.

\section{Materials and Methods}

\section{Type of Study}

In this descriptive study, the files of the patients who were registered in the Adult Emergency Department of Medical Faculty Hospital between October 2015 and September 2017 due to occupational accident were examined retrospectively from the automation system.

The age and gender of the patients, admission time, reason of complaint, the sector in which the patient works (construction, textile, machinery-metal, service, transport-transportation, trade-office, agriculture-livestock, energy and other) were evaluated. Also, trauma to the body area due to the accident (head and neck, thorax, abdomen-pelvis, upper extremity, lower extremity) and patient' costs to SSI were determined according to the hazard classification of the business lines (less dangerous, dangerous, very dangerous). For this, a total of 410 patients with complete data were included in the study. Patients with missing file information, demographic data and cost reports, who were younger than 12 years and over 100 years of age were excluded from the study.

Our study was approved with the decision of the local ethics committee on 25.10.2017 (decision no: 09).

\section{Statistical Analysis}

Demographic data were summarized as numbers and percentages. While evaluating the cost, the sectors where the applicants work were divided into three groups as less dangerous, dangerous and very dangerous, based on the Occupational Health And Safety Communication of Employment Danger Classes. The construction sector, the machinery-metal sector, the transport-transportation sector and the energy sector were considered as very dangerous business lines whereas textile and agriculture were examined in the class of dangerous business and the service sector, trade-office work, food sector and wood carving sector were examined in the class of less dangerous business lines. Shapiro-Wilk test was used to determine whether the numerical measurements correspond to normal distribution. As a result of this evaluation, numerical measurements were presented as median and minimum-maximum. A regression tree model was used to determine the factors that affect costs. $P$ values below $5 \%$ were considered statistically significant. SPSS 16.0 package program was used for the analysis and $R$ 3.3.2. Software was used for regression tree analysis.

\section{Results}

A total of 410 patients who admitted to the emergency department due to occupational accidents were included in the study. Of the patients, $95.9 \%$ were male. The mean age was found to be $33.08 \pm 10.68$ and $26.3 \%$ of the patients were aged 25 or under, $35.4 \%$ were between $26-35$ years of age, and $38.3 \%$ were 36 years and over. Thirteen patients (3.1\%) were determined to be 17 or under. Of those who had occupational accidents, $30.0 \%$ were working in construction sector, $20.7 \%$ in textile sector and $20.0 \%$ in machinery-metal sector. The demographic characteristics of the patients who admitted with an accident at work are presented in Table 1.

When the admission time to the hospital was evaluated, the maximum number of admissions was between 08:00-12:00 hours with a frequency of $34.6 \%$ and, of the admissions $30 \%$ were between 12:00-16:00 hours. Of the applications 30.2\% were due to incision, $29.5 \%$ due to crush and $26.8 \%$ due to falls. It was determined that upper extremities were the most affected body part due to work accidents. The clinical characteristics of the applicants with regard to occupational accidents were summarized in Table 2. 
Of the 410 patients, $84.1 \%(n=345)$ were discharged after being treated in the emergency department whereas $13.9 \%(n=57)$ patients were hospitalized. Of the patients who were hospitalized,

\begin{tabular}{|l|l|l|}
\hline $\begin{array}{l}\text { Table 1. Demographic characteristics of the patients who } \\
\text { admitted due to an accident at work }\end{array}$ & Number & Percentage \\
\hline Demographic characteristics & 108 & 26.3 \\
\hline Age (year) & 145 & 35.4 \\
\hline 25 or under & 157 & 38.3 \\
\hline $26-35$ & \multicolumn{2}{|l|}{} \\
\hline 36 years and over & 393 & 95.9 \\
\hline Gender & 17 & 4.1 \\
\hline Male & \multicolumn{2}{|l|}{} \\
\hline Female & 123 & 30.0 \\
\hline Sector & 85 & 20.7 \\
\hline Construction sector & 82 & 20.0 \\
\hline Textile sector & 34 & 8.3 \\
\hline Machinery-metal sector & 20 & 4.9 \\
\hline Service sector & 20 & 4.9 \\
\hline Transport-transportation sector, & 13 & 3.2 \\
\hline Trade-office work & 11 & 2.7 \\
\hline Agriculture and livestock & 22 & 5.4 \\
\hline Energy sector & \multicolumn{2}{|l|}{} \\
\hline Other (Food industry, wood carving) & \\
\hline
\end{tabular}

Table 2. Clinical characteristics of the applicants due to occupational accidents

\begin{tabular}{|c|c|c|}
\hline Clinical characteristics & Number & Percentage \\
\hline \multicolumn{3}{|l|}{ Time of admission } \\
\hline 8:00 a.m. - 12:00 p.m. & 142 & 34.6 \\
\hline 12:00 p.m. - 4:00 p.m. & 123 & 30.0 \\
\hline 4:00 p.m. - 12:00 a.m. & 105 & 25.6 \\
\hline 12:00 a.m. - 08:00 a.m. & 40 & 9.8 \\
\hline \multicolumn{3}{|l|}{ Reason of complaint } \\
\hline Incision or rupture & 124 & 30.2 \\
\hline Crushing & 121 & 29.5 \\
\hline Falls & 110 & 26.8 \\
\hline Eye injury & 20 & 4.9 \\
\hline Other $^{\mathrm{a}}$ & 35 & 8.6 \\
\hline \multicolumn{3}{|l|}{ Trauma area } \\
\hline Upper extremity & 193 & 47.1 \\
\hline Head and neck & 99 & 24.1 \\
\hline Lower extremity & 52 & 12.7 \\
\hline Thorax & 28 & 6.8 \\
\hline Abdomen-pelvis & 25 & 6.1 \\
\hline No trauma & 13 & 3.2 \\
\hline
\end{tabular}

73.6\% were referred to the orthopedics and traumatology clinic, $11.3 \%$ to the ophthalmology clinic, $5.6 \%$ to the anesthesia intensive care unit, 3.8\% to the neurosurgery clinic and 1,9\% to the plastic and reconstructive surgery, cardiovascular surgery and urology clinics.

When the forensic reports were evaluated, it was determined that $2 \%(n=8)$ of the patients had died due to injury whereas $1.7 \%(n=7)$ of the patients had a life-threatening condition and $96.3 \%$ of the patients had no risk of death.

The total cost of emergency services invoices of the 410 patients who applied due to occupational accidents to SSI was calculated as 54.152.77 も.

A regression tree model was used to determine the factors that affect costs. In the model, examination findings (multitrauma, corrosive intake, fracture, dislocation, soft tissue injury, amputation, skin cut, tendon cut, vessel cut abrasion), reason of complaint (Incision or rupture, explosion-burning, electric shock, poisoning, traffic-service accident, eye injury, falls, crushing), trauma area (abdomen-pelvis, thorax, lower extremity, head and neck, upper extremity), prognosis (hospitalisation, exitus, discharged), age, gender and degreee of danger (less dangerous, dangerous, very dangerous). The most important variables in estimating the cost were examination findings, reason of admission, traumatic region, prognosis and age. The effect of danger classification and gender on cost was very limited and insignificant (Figure 1).

\section{Discussion}

Occupational accidents are an important public health problem considering both physical and pecuniary damages they cause. Therefore, the aim of our study was to evaluate the clinical

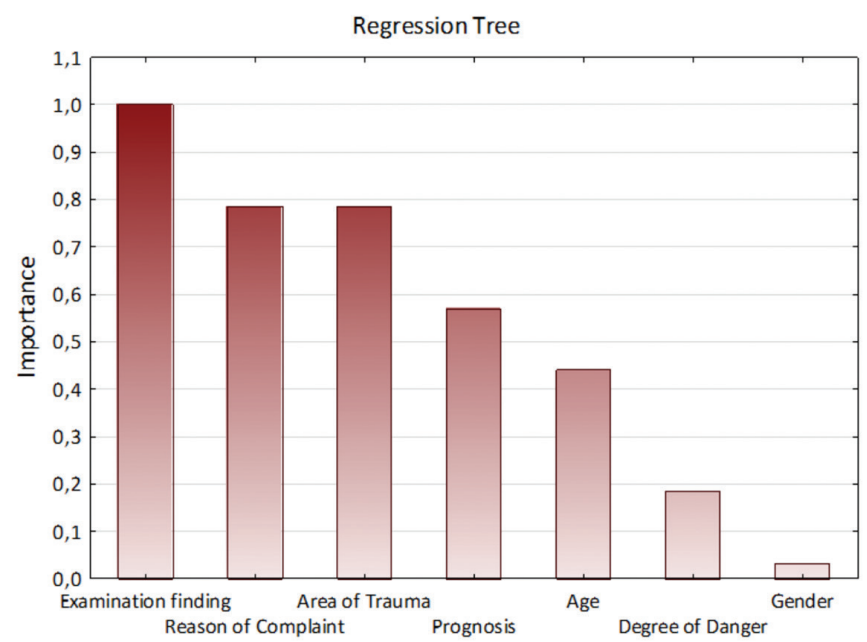

Figure 1. Factors affecting the costs due to occupational accidents (dependent variable: cost) 
aspects of occupational accidents along with their emergency service costs.

According to the study of Karakurt et al. (12), 96.5\% of the people who had occupational accidents were male and $3.5 \%$ were female. In the study of Dagli and Serinken (13) it was found that this rate was $86.4 \%$ to $13.7 \%$. In other similar studies, occupational accident rates were found to be higher in males (84.4-98.7\%) $(14,15)$. In 2017 SSI data, this ratio was stated as $83.6 \%$ for males and $16.4 \%$ for females (7). Consistent with the literature, we also found that occupational accidents were more common in men. We consider that the main reason for this is the fact that women do not adequately take place in business life and that they work in less dangerous business areas where physical power is mostly not in the forefront. We also believe that women may act more rigorously than men to comply with occupational health and safety rules.

The distribution of occupational accidents by age groups in Turkey according to the data of SSI in 2016 was as follows: of the occupational accidents, $26.8 \%$ were in in people aged 25 and under, 35.3\% were in people between the ages of 26-35 and $35.8 \%$ were in people who were the age of 36 and over (16). In an analysis that compared the occupational accident data in our country and the European Union, it was stated that the age range where occupational accidents were most common was between 22-29 years in our country and 25-34 years in the European Union (17). In many studies, the average age of those exposed to occupational accidents was found to be between 25 and 32 years and it was determined that the most risky age group in terms of occupational accidents was between 21-30 years of age $(15,18-20)$. In our study, similar results to the data of SSI in 2016 were obtained and occupational accidents were mostly seen at the age of 36 years and over and secondly at the age between 26 and 35 years. As a result of the fact that the young-adult age group employees are more preferred in risk-bearing jobs and the employees of this age group are more likely to take risks during their work, occupational accidents occur in these age groups at a higher rate. In the SSI data, the rate of occupational accidents at the age of 17 years is below 2.2\% (16). In our study, this rate was slightly higher (3.1\%) and this situation is thought to be caused by the high number of migrant population in our province.

In a study conducted among the cleaning workers in our country, it was reported that the most common type of injury was incision and rupture (21). In another study, the most common type of injury was also incision and rupture and it was shown that this was followed respectively by crushing, falls and traffic accidents (18). In our study, the results were obtained similar to the literature. The most frequent injuries were due to incision and rupture (30.2\%), thereafter due to crushing (29.5\%) and then due to falls (26.8\%). The reasons for the incidence of incision and rupture injuries in occupational accidents can be listed as the lack of compliance with the principles of occupational health and safety and the dependence of the basic laखbor force on manpower.

In a study conducted by Dagli and Serinken (13), the most frequent occupational accidents were reported as machinery-metal, textile and construction, respectively. In another study, sectors with the highest number of occupational accidents were reported as manufacturing, construction and agriculture, respectively (15). When the SSI data of the year 2016 were examined, it was seen that the construction sector was with the highest number of occupational accidents and that this was followed by the machine-metal sector (16). In our study, the sectors in which the occupational accidents were encountered most frequently were found similar to those of SSI data and were respectively construction, textile and machine-metal sector. These sectorial differences between the studies are thought to be caused by the industrial and commercial activities that are predominant in the province as well as the proximity of the location of the factories to the hospital where the study was conducted. The years when the studies are carried out are also important. Considering that activities related to infrastructure and superstructure in our country have increased rapidly in recent years, it is a foreseeable situation that most of the occupational accident is in the construction sector.

According to the occupational accident data of the Turkish Statistical Institute (TURKSTAT) between the years 2003-2005, it has been reported that occupational accidents occurred mostly within the first 3 hours after the start of the work (22). In a study conducted in our country, it was stated that accidents occur most between 08:00a.m and 16:00p.m (13). The findings our study is concordant to the data of TURKSTAT and the literature. Occupational accidents were determined to be most common between 08:00a.m-12:00 p.m hours. The reason why occupational accidents are more common in the morning is thought to be the result of lack of concentration at the time of start working.

In our study, the most common injury was found to be extremity injury with $59.8 \%$ in the cases who applied for occupational accident. It was also determined that the upper extremity (47.1\%) was the region that was mostly exposed to trauma. In the data of SSI in 2016, the most frequently injured area was the extremity (57.1\%) and the injuries of the upper extremity (38.2\%) came first (16). Similar to our study, it has been found that upper extremities were most frequently injured in occupational accidents in our country $(12,19,23)$. In jobs that require skill in all areas of work, the widespread use of upper extremities, particularly hands, has been envisaged as the main cause of this condition. 
In a study, the rate of discharge from the emergency department was $90 \%$ and the rate of hospitalization was $7 \%(15)$. In another study, this rate was found to be $62.9 \%$ and $35.6 \%$ (19), and in another one $40.7 \%$ of the patients were treated as outpatient (24). In our study, the majority of patients were discharged after being treated in the emergency department. It was determined that a small number of the patients were treated by hospitalization. In terms of differences in hospitalization rates, we believe that the number of serious or mild cases is due to the diversity of applications, depending on the distance of the hospitals to the industrial zones and city centers. In most of the studies in the literature, orthopedics clinic is one of the most frequently clinics, where hospitalization is performed $(12,19,25)$. In our study, this situation is similar to the literature and the patients were mostly referred to the orthopedics clinic.

Although more attention is paid to occupational health and safety issues in recent years, deaths related to occupational accidents are still observed. Mortality rates in European Union countries were determined as $0.16 \%$ in 2014 and $0.15 \%$ in 2015. In our country, the mortality rate in occupational accidents was determined as $0.71 \%, 0.73 \%, 0.51 \%$ and $0.49 \%$ between 2013 and 2016, respectively (17). In addition, in different studies conducted in our country, this rate is stated as $0.95 \%$ (12), 4.9\% (18), 1\% (15) and there are differences between the studies. This rate was found to be $2 \%$ in our study and it is similar to the literature studies in our country, but it is higher than the data of SSI. Our clinic is the emergency clinic of a tertiary university hospital, therefore it is the first clinic of choice for the transfer of severe cases by emergency line. We believe that the high mortality rate may be due to this fact. It is also noteworthy that the mortality rate in our country is higher than in the EU countries.

When the literature is examined, there are not enough studies examining the cost analysis in occupational accidents and this issue has been pointed out in our study. The most crucial independent variables in estimating the costs were examination findings, reason of admission, traumatic region, prognosis and age. The effect of danger classification and gender on cost was very limited and insignificant. The total cost of emergency services for the 410 patients who applied due to occupational accidents was calculated as $54,152,77$, which only represents the direct emergency costs to SSI. Considering that 359,653 occupational accidents had occurred in 2017, with an optimistic estimation approximately 48,000,000 $€$ would only be the amount of direct annual emergency costs to SSI due to occupational accidents. When the indirect costs, such as workday loss, court costs, damage to and/or loss of equipment, work interruption, inspection process, mood disorders and rehabilitation costs were taken into account, it would be easily recognized that pecuniary costs caused by occupational accidents is a serious burden for a developing country such as Turkey.

\section{Study Limitations}

This study however has some limitations. Firstly, this study included only data of our hospital for occupational accidents which obstructed us to extrapolate the results. Secondly as it is a retrospectively planned study relying on the quality of the medical records, we could not make further estimations regarding costs, particularly the indirect ones. Despite its limitations, we believe that this study may shed light on future studies. We recommend further analytical studies to be conducted especially to address the indirect costs of occupational accidents.

\section{Conclusion}

In our country, occupational accidents cause most deaths after traffic accidents and home accidents and they are serious type of accidents which cause the majority of permanent injuries. Occupational accidents, which are an important public health problem, have a significant negative impact on both workers' health and the national economy. Particularly in workplaces classified as dangerous and very dangerous, employees are at risk for accidents that can cause permanent injury and death. Therefore, the occupational health and safety measures required by our legislation must be taken at all workplaces. The main objective should be to establish occupational health and safety culture in employers and employees and to control the risk factors at the source before these accidents occur. Adequate levels of inspections on occupational health and safety at workplaces will lead to a reduction in the number of accidents that may occur and consequently to a decrease in losses.

\section{Acknowledgements}

We thank Dr. Adem Doğaner for this contribution in statistical analyses.

\section{Ethics}

Ethics Committee Approval: Our study was approved with the decision of the local ethics committee on 25.10.2017 (decision no: 09).

Informed Consent: Retrospective study.

Peer-review: Externally peer-reviewed.

\section{Authorship Contributions}

Surgical and Medical Practices: H.H., C.Ö., Concept: H.H., R.A.O., M.S.G., A.I.K., Ö.G., Design: H.H., C.Ö., R.A.O., M.S.G., A.I.K., Ö.G., F.N.Y., M.K., Data Collection or Processing: H.H., C.Ö., R.A.O., M.S.G., A.I.K., Ö.G., F.N.Y., M.K., Analysis or Interpretation: H.H., 
C.Ö., R.A.O., M.S.G., A.I.K., Ö.G., F.N.Y., M.K., Literature Search: H.H., C.Ö., R.A.O., M.S.G., A.I.K., Ö.G., F.N.Y., M.K., Writing: H.H., C.Ö., R.A.O., M.S.G., A.I.K., Ö.G., F.N.Y., M.K.

Conflict of Interest: No conflict of interest was declared by the authors.

Financial Disclosure: The authors declared that this study received no financial support.

\section{References}

1. Seo DC. An explicative model of unsafe work behavior. Safety Science. 2005;43:187-211

2. Özkılıç Ö. İş Sağlığı ve Güvenliği Yönetim Sistemleri ve Risk Değerlendirme Metodolojileri, TiSK Yayınları, Ankara, Türkiye, 2005.

3. Camkurt MZ. İşyeri Çalışma Sistemi ve İşyeri Fiziksel Faktörlerinin Iș Kazaları Üzerindeki Etkisi. TüHis İş Hukuku ve İktisat Dergisi. 2007;20/21:80-106.

4. Güler M. İşçi Moralinin Önemi ve Verimlilik. Hacettepe Üniversitesi İktisadi ve İdari Bilimler Fakültesi Dergisi. 1996;14:189-99.

5. Atılgan A, Ersen $\mathrm{N}$, Peker $\mathrm{H}$, Kahraman $\mathrm{N}$. Türkiye mobilya sanayinde iş kazası ve meslek hastalıklarının önlenmesine ilişkin tavsiyeler. Selçuk Teknik Dergisi. 2015;14:664-83.

6. International Labour Organization (ILO). Safety and health at work. http:// www.ilo.org/global/topics/safety-andhealth-at-work/lang--en/index.htm

7. 5510 Sayılı Kanunun 4-1/a Maddesi Kapsamındaki Sigortalılardan İs Kazası Geçiren ve Meslek Hastalığına Tutulan Sigortalı Sayılarının Ekonomik Faaliyet Sınıflamasına ve Cinsiyete Göre Dağılımı, 2017. http://www.sgk.gov.tr/wps/ portal/sgk/tr/kurumsal/istatistik/sgk_istatistik_yilliklari

8. 5510 Sayılı Kanunun 4-1/a Maddesi Kapsamındaki Sigortalılardan İs Kazası Geçiren ve Meslek Hastalığına Tutulan Sigortalı Sayılarının Illere ve Cinsiyete Göre Dağılımı, 2017.

9. Ceylan H. Türkiye'deki iş kazalarının genel görünümü ve gelișmiş ülkelerle kıyaslanması. International Journal of Engineering Research and Development 2011;3:18-24.

10. Kadıŏlu E, Karaman S, Arık Ö. İs Kazası Nedeniyle Acil Servise Başvuran Hastaların Demografik Analizi. Gaziosmanpaşa Üniversitesi Tıp Fakültesi Dergisi. 2016;8:163-73.
11. Karakurt Ü, Satar S, Bilen A, Açıkalın A, Gülen M. Occupational Accidents and Emergency Medicine. JAEM. 2012;11:227-37.

12. Karakurt Ü, Satar S, Açıkalın A, Bilen A, Gülen M, Baz Ü. Analysis of Occupational Accidents Admitted to the Emergency Medicine Department. JAEM. 2013;12:19-23.

13. Dagli B, Serinken M. Occupational injuries admitted to the emergency department. JAEM. 2012;11:167-70.

14. Cantürk G, Eșiyok B, Yașar H, Doğan B, Hancı H. İș Kazası Nedeniyle 19932003 Yılları Arasında Ankara Üniversitesi Tıp Fakültesi Adli Tıp Anabilim Dalına Bașvuran Olguların Değerlendirilmesi. Erciyes Tıp Dergisi. 2000;28:16

15. Özkan S, Kılıç \$, Durukan P, Akdur O, Vardar A, Geyik S, et al. Occupational injuries admitted to the Emergency Department. Turkish Journal of Trauma \& Emergency Surgery. 2010;16:241-7.

16. 2018. Yıllık is Kazaları istatistikleri / 2016 Yılı iş Kazası Ve Meslek Hastalıkları istatistikleri. https://tuisag.com/2016-yili-is-kazasi-meslek-hastaliklari-istatistikleri/

17. Öçal M, Çiçek Ö. Comparative analysis of occupational accidents data in Turkey \& EU. HAK-iş Uluslararası Emek ve Toplum Dergisi. 2017;6:616-37.

18. Kalemoğlu M, Keskin Ö, Yıldııım I, Erşanlı D. Acil servise başvuran travmatik iş kazalarının incelenmesi. Nobel Med. 2006;2:21-3.

19. Sunay YM, Asirdizer M, Ulucay T, Zeyfeoglu Y, Erbuyun K, Gullucayir S. Iş kazası sonucu acil servise müracaat eden olgular. 6 . Anadolu Adli Bilimler Kongresi 2007, Manisa:102-7.

20. Kekeç Z, Ünalan D, Şenol V, Çetinkaya F. Erciyes Üniversitesi Tıp Fakültesi Acil Servisine Başvuran İş Kazalarının Değerlendirilmesi. Fırat Üniversitesi Sağılı Bilimleri Tıp Dergisi. 2003;17:277-83.

21. IIhan MN, Kurtcebe ZÖ, Durukan E, Koșar L. Temizlik Isșçilerinin Sosyodemografik Özellikleri ve Çalışma Koşulları ile iş Kazaları ve Meslek Hastalıkları Sıklığı. Fırat Üniversitesi Sağlık Bilimleri Dergisi. 2006;20:433-9.

22. TUiK İş Kazaları istatistikleri: Iş kazalarının meydana geldiği iş saatlerine göre dağılımı 2003-2005, 2011. http://www.tuik.gov.tr/PreTablo.do?tb_

23. Akdur O, Ozkan S, Durukan P, Avsarogullari L, Koyuncu M, Ikizceli I. Machinerelated farm injuries in Turkey. Ann Agric Environ Med. 2010;17:59-63.

24. Beyaztaş FY, Alagözlü H, Demirkan O. The evaluation of occupational injury cases in the frame of forensic medicine. J For Med. 2001;15:18-24.

25. Satar S, Kekeç Z, Sebe A, Sarı A. Çukurova Üniversitesi Tıp Fakültesi Acil Tıp Anabilim Dalına Başvuran İş Kazası Olgularının Analizi. Çukurova Üniversitesi Tıp Fakültesi Dergisi. 2004;29:118-27. 